\title{
Collaborative Learning in Higher Education: Evoking Positive Interdependence
}

\author{
Karin Scager, ${ }^{+*}$ Johannes Boonstra, ${ }^{\ddagger}$ Ton Peeters, ${ }^{\ddagger}$ Jonne Vulperhorst, ${ }^{\dagger}$ \\ and Fred Wiegant* \\ ${ }^{\dagger}$ Department of Social Sciences, Utrecht University, 3508 TC Utrecht, The Netherlands: \\ "Department of Biology, Utrecht University, $3584 \mathrm{CH}$ Utrecht, The Netherlands
}

\begin{abstract}
Collaborative learning is a widely used instructional method, but the learning potential of this instructional method is often underused in practice. Therefore, the importance of various factors underlying effective collaborative learning should be determined. In the current study, five different life sciences undergraduate courses with successful collaborative-learning results were selected. This study focuses on factors that increased the effectiveness of collaboration in these courses, according to the students. Nine focus group interviews were conducted and analyzed. Results show that factors evoking effective collaboration were student autonomy and self-regulatory behavior, combined with a challenging, open, and complex group task that required the students to create something new and original. The design factors of these courses fostered a sense of responsibility and of shared ownership of both the collaborative process and the end product of the group assignment. In addition, students reported the absence of any free riders in these group assignments. Interestingly, it was observed that students seemed to value their sense of achievement, their learning processes, and the products they were working on more than their grades. It is concluded that collaborative learning in higher education should be designed using challenging and relevant tasks that build shared ownership with students.
\end{abstract}

\section{INTRODUCTION}

Students may learn a lot from working in groups, but the learning potential of collaboration is underused in practice (Johnson et al., 2007), particularly in science education (Nokes-Malach and Richey, 2015). Collaborative, cooperative, and team-based learning are usually considered to represent the same concept, although they are sometimes defined differently (Kirschner, 2001); we consider these concepts comparable and use the term "collaboration" throughout the paper. In collaborative learning, students participate in small-group activities in which they share their knowledge and expertise. In these student-driven activities, the teacher usually acts as a facilitator (Kirschner, 2001).

Several decades of empirical research have demonstrated the positive relationship between collaborative learning and student achievement, effort, persistence, and motivation (for reviews, see Slavin, 1990; Webb and Palinscar, 1996; Barron, 2000; Johnson et al., 2007). Collaborative learning potentially promotes deep learning, in which students engage in high-quality social interaction, such as discussing contradictory information (Visschers-Pleijers et al., 2006). In science education, a deep-learning approach is crucial for understanding concepts and complex processes (Van Boxtel, 2000). Understanding of these concepts involves a process of conceptual change, a process particularly activated in collaborative learning, whereby students interact by explaining to and questioning one another critically (Van Boxtel et al., 2000; Linton et al., 2014). In previous papers, we have explored and emphasized the relevance of collaborative learning in undergraduate biology courses (Wiegant et al., 2012, 2014). By comparing university student achievement
Jennifer Knight, Monitoring Editor

Submitted July 14, 2016; Revised August 23, 2016 Accepted September 13, 2016

CBE Life Sci Educ December 1, 2016 15:ar69 DOI:10.1187/cbe.16-07-0219

*Address correspondence to: Karin Scager (k.scager@uu.nl).

() 2016 K. Scager et al. CBE-Life Sciences Education () 2016 The American Society for Cell Biology. This article is distributed by The American Society for Cell Biology under license from the author(s). It is available to the public under an Attribution-Noncommercial-Share Alike 3.0 Unported Creative Commons License (http://creativecommons.org/licenses/ by-nc-sa/3.0)

"ASCB®" and "The American Society for Cell Biology $\AA^{\prime \prime}$ are registered trademarks of The American Society for Cell Biology. 
in a biology course in individual and group settings, Linton et al. (2014) found that students in group settings achieved significantly better with respect to conceptual understanding in comparison with students in courses with an individual setting. Besides these cognitive benefits, collaborative learning provides social skills needed for future professional work in the field of science.

Just forming groups, however, does not automatically result in better learning and motivation (Salomon and Globerson, 1989; Gillies, 2004; Khosa and Volet, 2013). In their study of university students' preferences for collaborative learning, Raidal and Volet (2009) found an overwhelming preference for individual forms of learning. Students are hesitant about group work because of the occurrence of "free riders," logistical issues, or interpersonal conflicts (Livingstone and Lynch, 2000; Aggarwal and O'Brien, 2008; Pauli et al., 2008; Shimazou and Aldrich, 2010; Hall and Buzwell, 2012). As a result, students might opt for a strategic approach by dividing the work and merely using a stapler to "integrate" their work into a group paper. Johnson and Johnson (1999) refer to groups showing this kind of superficial behavior as "pseudo learning groups." In turn, the resulting lack of synthesis can be disappointing for teachers. Dividing work also implies that students lose the potential learning effect of collaborating, since the extent to which students benefit from working with other students depends on the quality of their interactions (Van Boxtel et al., 2000; King, 2002; Palinscar and Herrenkohl, 2002; Volet et al., 2009). Insight into factors that facilitate collaborative learning is critical for understanding how collaboration can be used effectively in higher education. Therefore, in the present study, we explore factors that optimize the quality of collaboration, using examples of effective group work in five different life sciences courses.

\section{POTENTIAL FACTORS ENHANCING THE EFFECTIVENESS OF COLLABORATIVE LEARNING}

Social interaction is crucial for effective collaboration (Volet et al., 2009). Learning outcomes of collaborative-learning groups have been found to depend on the quality of student discussions, including argumentation (Teasley, 1995; Chinn et al., 2000), explaining ideas to one another (Veenman et al., 2005), and incorporating and building on one another's ideas (Barron, 2003). These interactions with peers are assumed to promote students' cognitive restructuring (Webb, 2009). Explaining things to one another and discussing subject matter may lead to deeper understanding, to recognition of misconceptions, and to the strengthening of connections between new information and previously learned information (Wittrock, 1990). The question of how to organize collaboration in a way that promotes these kinds of interactions is paramount.

Decades of research on group work have resulted in the identification of various factors that potentially enhance the effectiveness of collaboration. These factors can be differentiated as primary factors (design characteristics) and secondary or mediating factors (group-process characteristics). Regarding primary factors, groups need to be small (three to five students) to obtain meaningful interaction (Lou et al., 2001; Johnson et al., 2007). With respect to group composition, mixed-ability groups have been found to increase performance for students of lower ability, but this composition does not necessarily benefit high-ability students (Webb et al., 2002). Equal participation, however, has been shown to be more important for students' achievement than group composition, because students are more likely to use one another's knowledge and skills fully when all students participate to the same extent (Woolley et al., 2015). Heterogeneity, with respect to diversity of perspectives and styles, has been found to increase learning, particularly in groups working on tasks that require creativity (Kozhevnikov et al., 2014). The nature of the task has been shown to be an important factor as well. Open and ill-structured tasks promote higher-level interaction and improve reasoning and applicative and evaluative thinking to a greater extent than closed tasks (Gillies, 2014). In addition, complex tasks provoke deeper-level interactions than simple tasks (Hertz-Lazarowitz, 1989).

Concerning secondary or intermediate factors affecting group work, positive interdependence theory is one of the bestfounded theories explaining the quality of interaction in collaborative learning (Slavin, 1990; Johnson and Johnson, 1999, 2009; Gully et al., 2002). According to this theory, collaboration is enhanced when positive interdependence exists among group members. This is achieved when students perceive the contribution of each individual to be essential for the group to succeed in completing the assigned activity (Johnson and Johnson, 2009). Positive interdependence results in both individual accountability and promotive interaction. Individual accountability is defined as having feelings of responsibility for completing one's own work and for facilitating the work of other group members. A sense of mutual accountability is necessary to avoid free riding (Johnson and Johnson, 2009), which occurs when one or more group members are perceived by other members as failing to contribute their fair share to the group effort (Aggarwal and O'Brien, 2008). Promotive interaction has been described as students encouraging and facilitating one another's efforts to accomplish group goals, both with respect to group dynamics and the subject matter (Johnson and Johnson, 2009).

Methods of inducing positive interdependence interaction are either reward or task based (Johnson et al., 2007). Rewardbased interdependence structures the reward in such a way that students' individual grades depend on the achievement of the whole team. According to Slavin (1991, 1995), collaborative learning is rarely successful without group rewards. In higher education, however, findings on the effects of reward-based interdependence are inconclusive. The main concern is that rewards stimulate extrinsic motivation and may be detrimental to intrinsic motivation (Parkinson and St. George, 2003). Intrinsically motivated students put effort into a task because they are interested in the task itself, while extrinsically motivated students are interested in the reward or grade (Deci and Ryan, 2000). Strong incentives, such as grades, could steer student motivation toward the reward and subsequently reduce the task to being a means to an end. Serrano and Pons (2007), however, found that using rewards (individual grades) created high positive interdependence in group work at a university level. They concluded that the reward structure did direct students' motivation toward final grades, while the task still aroused the interest of the students. In contrast, Sears and Pai (2012) found that rewards were not crucial factors affecting group behavior. Their study showed that groups continued to work even after the reward was removed, whereas the efforts of students working individually decreased after the reward was removed. 
In structured task-based interdependence, students are forced to exchange information; this can be achieved by assigning group members different roles, resources, or tasks (the "jigsaw" method) or by "scripting" the process, which involves giving students a set of instructions on how they should interact and collaborate (Kagan, 1994; Dillenbourg, 2002). The effects of task structuring on collaborative learning are, however, not clear (Fink, 2004; Hänze and Berger, 2007; Serrano and Pons, 2007). Hänze and Berger (2007) observed no differences in achievement between students who worked in jigsaw-structured groups and students who worked individually. In contrast, the observations of Brewer and Klein (2006) indicated that students in groups with given roles plus rewards interacted significantly more frequently than students in groups with given rewards only or in groups without structured interdependence factors. (Over)structuring interaction processes, on the other hand, could threaten intrinsic motivation and disturb natural interaction processes (Dillenbourg, 2002). Although it is widely accepted that positive interdependence has been shown to be crucial in evoking social interaction, in practice, university students often tend to merely go through the motions and choose the solution requiring the least effort, which explains why positive interdependence often does not emerge (Salomon and Globerson, 1989). Additional methods are necessary to encourage quality interactions that enhance learning. Moreover, the mixed results of university education studies concerning structuring interdependence-using either rewards or task structuring-do not solve the challenge of how to create interdependence without disturbing the intrinsic motivation of students. Forcing students to interact could endanger student autonomy and motivation, while merely putting students together has been shown to be ineffective.

\section{THE CURRENT STUDY}

Despite the considerable amount of research on collaborative learning, less is known about how to structure university-level group work in order to capitalize on the benefits of collaborative learning. The studies discussed earlier focused on primary and secondary education and are not fully applicable to higher education, because students in undergraduate classes may have different schedules and often have not met before. Moreover, group work of university students is mostly organized outside class hours in the absence of teachers. Furthermore, literature in this area may be limited in applicability, as many studies of factors affecting collaboration have used (quasi) experimental designs, in which outcomes of two or three designs were compared (Johnson and Johnson, 2009). A restriction of this method is that only the hypothesized independent variables are studied, while other important factors contributing to effectiveness might be overlooked. In our study, we approached the theme retrospectively, investigating the learning of student groups known to have collaborated and achieved highly, according to their teachers. Rather than focusing on learning outcomes, we explored how group work in these courses was structured. Understanding the factors that facilitate students' collaboration is critical to understanding how this approach to learning can be used more effectively in higher education. We explicitly focused on positive examples of effective collaborative learning, as best practices should be communicated to others (Dewey, 1929, p.11).
In the current study, we selected five different life sciences undergraduate courses that comprised successful group-work assignments. The specific question this study aimed to address was, according to the students, what factors increased collaboration in these courses? By uncovering the factors that make collaborative learning fruitful, we aim to provide useful guidelines for instructors implementing collaborative learning.

\section{METHODS \\ Participants}

The present study involved focus group interviews with nine groups of second- and third-year students of five different undergraduate life sciences courses. We depended heavily on these focus group interviews to develop our understandings. They allowed us to gain insight into students' perspectives, which is important because, to a large degree, students' perspectives of instruction affect what they do and learn (Shuell, 1996). Furthermore, the group exchanges of experiences and perspectives promoted breadth, as well as depth, in our understandings of the cognitive, behavioral, and situational factors contributing to the effectiveness of the collaboration. The particular courses were selected because they all implemented group work that, according to teacher assessments and student evaluations, was very effective. We approached the instructors of these courses with the request to ask their students to volunteer in focus group discussions. Students were willing to participate in these focus group discussions, although not all students were able to meet at the scheduled times. No specific reward was promised for participating in focus group discussions.

Between two and 10 students participated in each of the nine focus group interviews (see Table 1).

\section{Course Descriptions}

We focused on five courses that were all small-enrollment, upper-division courses in which 15-35 students participated per course. In all courses, collaborative activities occurred during class hours but also outside of class. In some courses, the out-of-class cooperative activities even exceeded the in-class activities.

Course A: The first course was part of a biology honors program. In this part of the program, groups of second-year bachelor's students (12-19 students) were assigned the group task of writing a popular science book about a biology topic of their choice. Students had to perform all the activities necessary to produce the book. The project was strongly student-led, and students assigned themselves tasks necessary for finishing the project. The assignment comprised an entire academic year,

TABLE 1. Course, number of focus group interviews, and students per interview

\begin{tabular}{lcc}
\hline Course & $\begin{array}{c}\text { Number of focus } \\
\text { group interviews }\end{array}$ & $\begin{array}{c}\text { Students per } \\
\text { interview }\end{array}$ \\
\hline A. Biology honors book project & 3 & $2 ; 6 ; 6$ \\
B. Immunology & 2 & $5 ; 5$ \\
C. Advanced cell biology & 1 & 10 \\
D. Molecular cell biology & 1 & 3 \\
E. Quality Studies in Pharmacy & 2 & $6 ; 6$
\end{tabular}


starting in September and finishing in May/June as an extracurricular activity. More details of this course are described elsewhere (Wiegant et al., 2012).

Course B: Students in the immunology course, mostly thirdyear students, were assigned the task of writing, in groups of four, a short research project on an immunological topic. The assignment was structured in three parts: in part 1, groups designed a draft of their proposal; in part 2, the groups peer reviewed the draft of another group; and in part 3, the groups received the draft and comments of yet another group, which they had to finish and present. The assignment comprised approximately half of the course.

Course C: In the advanced cell biology course, three small teams of four or five students collaborated intensively during a semester of 15 weeks to formulate three $\mathrm{PhD}$ proposals within an overarching theme. Because the course was student-led, the teachers refrained from guiding the students in their decisions, instead taking a facilitating role by asking critical questions and providing feedback. As a result of the project, the teams presented and defended their research program and the three research proposals before a jury of experts. More details of this course are given elsewhere (Wiegant et al., 2011, 2014; Scager et al., 2014).

Course D: The objective of the molecular cell biology course was to learn to design a research project in groups of four. In this course, students were required to complete multiple assignments, such as reviewing a paper, developing a research proposal, designing experiments, and writing and defending their proposals. Groups met with their supervisor once a week and were supposed to keep the course coordinator informed on their progress. Final grades were based on individual (40\%) and group (60\%) components.

Course E: As a part of the pharmacy course, third-year students, in groups of four to six participants, were required to analyze the quality of a specific pharmacotherapy. The assignments were authentic and were provided by external commissioning companies. The group assignment counted for $70 \%$ of the final grade (50\% group report and presentation; $20 \%$ individual reflection).

\section{Interviews}

The interviews were semistructured and included two basic questions: 1) "What factors made group work effective in this course (as opposed to other experiences you have had)?" and 2) "What was the added value in this course of working in a group (as opposed to working individually)?" The addition of "as opposed to ..." was aimed to encourage students' thinking process; we did not ask students to elaborate on these opposing experiences. Interviewers stimulated and moderated discussions, ensuring depth as well as diversity. To focus and structure the interviews and to stimulate the sharing of discussion outcomes, we listed the answers to the two questions on a flip chart.

\section{Procedure}

First, the intentions of the interview were clarified, followed by an explanation of the confidential nature of the interview. All students agreed and gave permission for the interviews to be audiotaped. All of the authors conducted one or more interviews, with the first author (K.S.) moderating them. The focus group interviews were held in or near the classroom associated with each of the specific courses. The interviews were $\sim 60$ minutes each and were transcribed verbatim.

\section{Analysis}

Detecting Factors That Facilitated Group Work. Data were analyzed by the first and fourth authors (K.S. and J.V.) in three partially overlapping stages. Stage 1 comprised reading and rereading the transcripts to identify text units relevant to the subject of challenge. Given the aim of the focus group interviews, this meant ignoring small talk and sorting discussion units related to the two interview questions into focal issues. Stage 2 comprised identifying and coding themes related to the two main interview questions regarding 1) factors and 2) added value, using NVivo version 10 (a qualitative data-analysis computer software package). First, open coding was applied. The answers to both questions, however, evoked answers that pointed to intermediary variables affecting the outcomes of collaboration. For example, the question regarding factors brought forward the importance of the assignment being complex enough to make students feel mutually interdependent, while for the question regarding added value, students referred back to how the complexity of the assignment stimulated them to discuss, build on, and learn from one another's ideas. The interactions provoked by the complexity of the task seemed to connect complexity with learning outcomes. Therefore, when axial coding was applied, we decided to develop three clusters of codes focused on the factors of effective collaboration, the mediating variables, and the added value of collaboration. Subsequently, selective coding was applied, wherein codes were clustered into larger sets informed by theory (Braun and Clarke, 2006). Only factors that were mentioned in more than half of the focus groups were kept. This resulted in two sets of factors. The first set of factors related to the design of the group assignment (autonomy, group size, task design, and teacher expectations). The second set consisted of mediating variables related to the working processes of the groups (team and task regulation, promotive interaction, interdependence, responsibility, and mutual support and motivation).

Reliability and Validity. Reliability is considered in terms of equivalence and internal consistency (Sim and Wright, 2000). Reliability was ensured by intercoder consistency (Burla et al., 2008). Given the complexity and inhomogeneity of group discourse, agreement testing was constrained to core concepts or themes of substantive importance (Kidd and Parshall, 2000). The equivalence of coding was addressed by selecting $20 \%$ of the data and comparing the coding of two secondary raters (10\% each) for consistency, which yielded a kappa coefficient of 0.85 . This strength of agreement is considered to be "nearly perfect" (Everitt, 1996). Internal consistency was acquired by having one team member moderating all (but one) of the interviews (Kidd and Parshall, 2000). The emergence of substantively similar viewpoints of the focus groups on the core issues across the five different courses supported content validity (Kidd and Parshall, 2000). Furthermore, we assessed content validity by independent coding and by comparing this with theory in extant literature (Morgan and Spanish, 1985; Torn and McNichol, 1998). 


\section{RESULTS}

\section{Factors That Contributed to the Effectiveness of the Collaboration}

Eight factors were found to have a positive effect on the effectiveness of the collaboration. These factors are presented in Table 2: 1) design factors: the design of the course and/or the assignment (the autonomy of the students, task characteristics, teacher expectations, and group size); and 2) process factors: the way students interacted and organized their work (team and task regulation, interdependence, promotive interaction, and mutual support and motivation).

Table 2 shows that autonomy and the density and complexity of the task were the factors most frequently mentioned by the students as contributing to the effectiveness of the collaboration. Team and task regulation, positive interdependence, and promotive interaction were perceived by students as the most important factors with respect to the way they processed the assignments. In the next section, we describe the results more elaborately, starting with the design features of these courses that are considered to enhance collaboration processes.

\section{Design Factors}

The autonomy the groups experienced was mentioned in all focus groups, indicating the importance of this factor to the effectiveness of collaboration. Autonomy was manifested in allowing student groups to choose their own topics (e.g., for their research plans) and giving them independence in organizing their processes. Statements such as "It was our own thing" occurred frequently in all nine focus group discussions. The references to "our thing" indicate that the students made choices as a group, which could have restricted individual feelings of autonomy. The students, however, did not seem to have experienced clear boundaries between individual and group autonomy. Even though their personal ideas may have been overruled by the team, they still felt autonomous, because they made decisions democratically. As one of the students said, "When you participate in the decision process it is easier to accept than when the decision is made by the teacher."

Two features of the task were perceived as important contributors to the effectiveness of the group work. First, the density and complexity of the task was crucial. The group task

TABLE 2. Factors that contributed to the effectiveness of the collaboration

\begin{tabular}{|c|c|c|c|}
\hline Codes & Subcodes & $\begin{array}{l}\text { Number of sources } \\
\text { and references }^{\mathrm{a}}\end{array}$ & Examples \\
\hline \multicolumn{4}{|l|}{ Design factors } \\
\hline Autonomy & & $9 ; 49$ & $\begin{array}{l}\text { Student 1: It's also the independence, that we did everything ourselves, so you } \\
\text { feel more responsible. Student 2: The independence makes you more } \\
\text { motivated, you know, that it's your own thing. Student 3: And also, there's } \\
\text { no one you can technically blame. }\end{array}$ \\
\hline \multirow[t]{2}{*}{ Task } & $\begin{array}{l}\text { Density and } \\
\text { complexity }\end{array}$ & $7 ; 35$ & $\begin{array}{l}\text { Because group work is the core of this course, that's what makes it work ... this } \\
\text { is } 100 \% \text { of your grade so you also really learn how to work in a group } \\
\text { because you have to make it work. }\end{array}$ \\
\hline & Relevance & $6 ; 21$ & $\begin{array}{l}\text { It's important that we're feeling that we're doing it the same way people do it } \\
\text { later in the future, because if it's just a presentation or an essay then you } \\
\text { don't feel the same kind of pressure. }\end{array}$ \\
\hline Rewards & & $7 ; 19$ & $\begin{array}{l}\text { We have written a really cool article ... this is much nicer than exams, we now } \\
\text { have something useful. }\end{array}$ \\
\hline Group size & & $7 ; 18$ & If it is a small group you have no one who could technically take your part. \\
\hline \multicolumn{4}{|l|}{ Process factors } \\
\hline \multirow[t]{2}{*}{$\begin{array}{c}\text { Team and task } \\
\text { regulation }\end{array}$} & & $9 ; 71$ & $\begin{array}{l}\text { It was important that we made agreements at the start ..., for example that we } \\
\text { agreed to finish the report a week before the deadline, and about who did } \\
\text { what, and what the rules were, these kinds of things. }\end{array}$ \\
\hline & & & $\begin{array}{l}\text { Yes, you need the mutual responsibility more than in other courses. Because you } \\
\text { have more freedom, you are more willing to lay these things upon yourself. }\end{array}$ \\
\hline \multirow[t]{3}{*}{$\begin{array}{l}\text { Positive } \\
\quad \text { interdependence }\end{array}$} & $\begin{array}{l}\text { Needing one } \\
\text { another's } \\
\text { efforts }\end{array}$ & $9 ; 23$ & $\begin{array}{l}\text { I think you also need your group actually, in terms of being able to finish the } \\
\text { project, because the project we made was so large, you have to contribute to } \\
\text { get it done. }\end{array}$ \\
\hline & Responsibility & $6 ; 15$ & $\begin{array}{l}\text { There's the responsibility, because, when you write an essay individually, when } \\
\text { you screw up, the consequence is yours only. But now, you are with a large } \\
\text { group, and unconsciously, you have the feeling that it has to be good, } \\
\text { because otherwise others will suffer as well. }\end{array}$ \\
\hline & $\begin{array}{r}\text { Complementing } \\
\text { one another }\end{array}$ & $9 ; 26$ & $\begin{array}{l}\text { Everybody brings his specialty; we had one girl for example who knew a lot } \\
\text { about stem cells, something she likes a lot. }\end{array}$ \\
\hline Promotive interaction & & $9 ; 47$ & $\begin{array}{l}\text { Well, you have to discuss things ... and you always get a lot further because you } \\
\text { get so much feedback from everyone. }\end{array}$ \\
\hline $\begin{array}{l}\text { Mutual support } \\
\text { and motivation }\end{array}$ & & $5 ; 18$ & $\begin{array}{l}\text { Also there's the happiness because people get quite indulged with their project } \\
\text { and are really, really passionate about it, and it rubs off on one another } \\
\text { within the group. }\end{array}$ \\
\hline
\end{tabular}

a"Source" refers to how many of the nine interviews the topic was discussed in; "reference" refers to the total number of times the topic was discussed. 
needed to be extensive enough for the group members to really need one another's contributions to finish in time and complex enough to require them to discuss their work and provide one another with feedback. Second, students perceived the relevance of the task at hand to be an important feature. The task relevance was found in different aspects, depending on the assignment. For the biology honors groups, for example, the process of writing a popular science book and getting it published increased their feelings of doing something significant. The cell biology and immunology groups emphasized the relevance of doing research, in terms of formulating a relevant proposal in the same way as it is done "in the real world."

In terms of rewards, students emphasized that the inherent value of the end product, such as an article, a research proposal, or a book, stimulated them to achieve, which relates back to the perceived task relevance. As a student of the biology honors course said, "We have also had other group projects ..., but that was taken less seriously, because you, well it was nice, but well, the result wouldn't reach beyond the classroom, while in this project it will." There were no grades involved in this particular course, which students appreciated, because they believed the end product to be more important than a grade. Also, in other groups, discussions about assessment were learning and/or reward oriented rather than grade oriented; for example, in one of the pharmacy groups it was said: "You are in a learning process, and I think sometimes that it is a shame that it should end in a grade-that creates a tension. And if things go wrong, that could be very beneficial for your learning, but it can also happen that you do not receive a high grade for it."

In all of the interviews, students mentioned that it was crucial that the task was the core project in the course at that time, as students of the immunology course stated: "I think also because this is not something you do on the side, but this is the only thing we do at the moment, it is the main activity." The fact that students' final grades depended primarily on the group assignment was mentioned in some groups. Students emphasized that in previous experiences with group assignments they had not collaborated as intensively because their final grade did not depend largely on the team assignment.

Finally, group size was considered a factor stimulating collaboration in seven of the groups, specifically related to the level of responsibility students felt. Groups of three or four were believed to be optimal: "Otherwise, you get a sort of diffuse responsibility ..., and with four you are clearly responsible for an important part of the process."

\section{Process Factors}

The need for team and task regulation was mentioned most frequently in the focus group discussions as an important factor increasing the effectiveness of collaboration. Students divided tasks, appointed team leaders, and set their own deadlines. Organizing frequent face-to-face meetings was very helpful, according to students: "That we met each other physically, instead of doing everything by mail or chat, like in other projects. This works much better, if you can look each other in the eyes it is way faster and more efficient to manage and decide things .... It also increases the pressure, everybody prepares for a meeting." The quote in Table 2 indicates the direct relation between the autonomy of the groups and their dedication to following their self-made group regulations.
As shown in Table 2, students in all nine focus groups experienced a sense of positive interdependence in terms of needing one another in order to succeed and achieve their goal. The feeling of responsibility was discussed in six groups. The related issue of "uneven contribution" was discussed in all nine of the focus groups: students did experience differences in power and effort between team members. Interestingly, students did not perceive this as free riding. According to the students, some degree of uneven contribution is only natural; the students all did their best, but as the students said, “There weren't students who contributed less; there were only students who contributed more." According to the students, this uneven contribution was due to power differences, not to disinterest or laziness. Students showed empathy for their peers who contributed less: "The strong people might go too hard for the other people to be able to catch up." This may have caused frustration in students who felt they were lagging behind, as one of them revealed: "You have that responsibility that drives you and then you feel the need to do more, but perhaps that is beyond your capabilities at that point." Some of the groups discussed the issue of uneven contribution while working on their projects, but always, they stated, in an "understanding and respectful way." Furthermore, students in all nine interviews mentioned the fact that the variety among students was useful and enhanced the discussions: "working in a group consisting of clones of yourself" would not be as interesting, one of the pharmacy groups stated.

All nine groups mentioned the need for promotive interaction several times, drawing attention to the need to discuss content to accomplish team goals. They mentioned several indicators of promotive interaction: discussions, exchange of information, and arguments, building on one another's ideas, explaining to one another, providing and processing peer feedback, and asking one another critical questions. According to the students, these discussions enhanced their understanding, and they also learned how to discuss, voice their opinion, explain, listen to others, accept feedback, and reflect on their own work.

Last, but not least, students talked enthusiastically about the way they supported and motivated one another. There was explicit help and pep talks, and, perhaps even more importantly, implicit mutual inspiration effected by them perceiving the motivation of their peers.

\section{Contextual}

Finally, we found one contextual factor (not included in Table 2) contributing to collaboration: the shared motivation of students to get the best out of the group assignment. Students mostly linked their having similar motivations to the fact that they were in their second or third year (four of the five courses were third-year courses). First, the students already knew one another: "When you are in your first year, you do not know each other, and some people are a bit insecure, so to say. But now we know each other, so we may scold each other all we can." Furthermore, students suggested being equally motivated, because the unmotivated students had already left in previous years.

\section{CONCLUSIONS AND DISCUSSION}

The purpose of the current study was to find factors that enhance student collaboration. The collaboration processes (task and team regulation, mutual support and motivation, 
positive interaction) used by these students were distinctly effective. During these processes, positive interdependence was clearly present, supporting the notion that positive interdependence is a crucial factor affecting the effectiveness of collaboration (Johnson and Johnson, 2009). Although the interview data do not allow causal relations between design factors and collaboration processes to be inferred, it seems reasonable to assume that positive interdependence was evoked by a combination of the nature of the task (autonomous, relevant, dense and complex, group rewards), the prominent placement of the group assignment within the course, and the group size.

\section{Process Factors}

The results indicate that positive interdependence was an important factor contributing to the effectiveness of collaboration. The positive effect of interdependence on student achievement has already been well documented (for reviews, see Slavin, 1990; Webb and Palinscar, 1996; Johnson et al., 2007). Although we disassembled the factors contributing to collaboration in the analysis, we assume interdependence does not consist of a single factor but rather is constructed through the interaction between motivated students and design factors (the nature of the task and student autonomy). Furthermore, the fact that the final grade depended primarily on the group assignment can be expected to have contributed to students' interdependence, which would concur with the findings of Slavin (1991). Interestingly, however, these students seemed to value the learning process and the products they were working on more than their grades. Our finding, that a sense of achievement rather than a grade was of greater importance in motivating interdependence, contradicts findings of Slavin (1991) and Tsay and Brady (2010). Tsay and Brady (2010) found that the degree of active participation of university students in collaborative groups was affected by the importance they attached to grades: students who perceived grades as highly important were more active collaborators.

The enthusiasm of the students when speaking of the way they supported and motivated one another and regulated the team and task processes indeed indicates the occurrence of strong self-regulatory processes. Although some structure was provided beforehand in all five courses (e.g., final deadlines), students were perceived to be autonomous in the planning and regulation of their work, which they said added to their motivation to follow their own rules and planning. This direct relationship between perceived autonomy and self-regulatory behavior is aligned with self-determination theory (Deci and Ryan, 2000). According to Deci and Ryan (2000), when teachers are supportive of student autonomy, students are motivated to internalize the regulation of their learning activities, whereas when teachers are controlling, self-regulated motivation is undermined. The self-regulatory social processes of these students, encouraged by the autonomy they were provided, were the most important factors increasing the effectiveness of their collaboration in these five cases.

Individual accountability is an important aspect within the theory of positive interdependence. Interestingly, instead of accountability, students used the word "responsibility." The difference between responsibility and accountability is meaningful, because accountability is focused on the end result, or being answerable for your actions to relevant others, while responsibility is related to the task. Responsibility is viewed as having a higher level of autonomy and involves the ability to self-regulate actions free of external motivational pressure. In contrast, the accountable actor is subject to external oversight, regulation, and mechanisms of punishment (Bivins, 2006). The term "responsibility" more appropriately fits the collaboration in these cases, as one of our participants illustrates: "You feel the responsibility to other people in your group, because as soon as soon as you drop the ball, the rest have to work harder." This student does not refer to consequences externally imposed on him, but he feels responsibility toward others. The effect this has may be the same as when students are forced to be accountable because of reward- or task-based structures, as suggested by Johnson and Johnson (2009); however, the nature of the motivation is more intrinsically than extrinsically induced.

Related to the issue of accountability or responsibility is the problem of free riding, which is one of the main problems of group work in higher education (Livingstone and Lynch, 2000; Aggarwal and O'Brien, 2008; Pauli et al., 2008; Shimazou and Aldrich, 2010). In the interviews in which the issue of free riding came up, however, groups did not seem to have experienced the phenomenon. A putative explanation for the lack of free-riding behavior is the incidence of accountability (Slavin, 1991; Johnson and Johnson, 2009; Onwegbuezie et al., 2009), as students definitely felt responsible for the end result. The way students spoke about their group members, however, was in terms of mutual trust rather than accountability. Students recognized differences in contribution but did not perceive this as problematic. They were empathic toward differences between students. If there were negative feelings at all, the low contributors were more apt to feel frustrated, indicating that the differences in contribution were, as Hall and Buzwell (2012) have suggested, involuntary and due to inadequacy rather than apathy or laziness.

\section{Design Factors}

In the five courses of this study, the combination of design factors seems to have prevented free riding. Although the causal nature of the relationship between design features of the group work and effective group processing cannot be claimed in the current study, the results indicate that, in particular, perceived autonomy and the challenging nature of the task evoked students' motivation to make an effort. The relevance of the tasks, which required students to produce something new (to them) and something original and tangible, motivated students. The tasks were also open and complex, which are features that have already been found to promote deeper-level interactions than simple tasks (Hertz-Lazarowitz, 1989; Cohen, 1994). Autonomy was a factor frequently mentioned as contributing to the effectiveness of the group work. Contradictory to Johnson and Johnson's (2009) recommendation for teachers to structure processes, students of these courses designated the autonomy they had in choosing their topic and in organizing the process, as one of the factors increasing their motivation. Results from organizational research show that autonomy can, in fact, increase teamwork achievement, but only when positive interdependence is high (Langfred, 2000). Autonomy combined with low interdependence decreases achievement, indicating 
that autonomy should be combined with challenging tasks. Although autonomy and level of challenge in a group assignment appears to be vital, instructors in different settings may need to use greater scaffolding.

\section{Future Research and Concluding Remarks}

It is important to keep in mind the small sample and restricted context when interpreting these findings. Although the results have been obtained in small-enrollment, upper-division courses, we think that our findings might also be transferable to large-enrollment courses, provided students will be working in self-directed small groups on substantial and relevant projects. As generalizability requires data on large populations, the findings of our five cases within a restricted context are not necessarily representative of the larger population. We believe, however, that there are strong reasons for our findings to be deemed "transferable" (Lincoln and Guba, 1985) to comparable situations. While generalization is applied by researchers, transferability is a process performed by the readers of research (Metcalfe, 2005). Unlike generalizability, transferability does not involve broad claims but invites readers of research to make connections between elements of a study and their own experiences (Barnes et al., 2012). According to Berliner (2002, p. 19), implementing scientific findings is always difficult in education, "because humans in schools are embedded in complex and changing networks of social interaction." Therefore, we do not claim to have produced broadly generalizable findings but instead invite the reader to identify how the findings can be transferred to his or her situation. Similar studies with data from other university contexts, such as other countries or other class settings, would help in understanding how the conditions that facilitate collaborative learning relate to different settings.

We assume, however, that the concept of evoking, rather than enforcing, positive interdependence by increasing autonomy and the challenge level of the task provides relevant insights for discourse on effective design of group work within life sciences education. Students in life sciences education, in general, are quite experienced in working in groups and in regulating their own work. Autonomy, combined with a challenging task, evoked interdependence and generated interaction as well as student motivation in these five cases. Structuring the process, for example by scripting, seems unnecessary for promoting student interaction. It was, in Dillenbourg's (2002) words, not necessary to "didactisise" collaborative interactions or to disturb the autonomy and natural interactions of students. Moreover, structuring the process could have impeded the feeling of autonomy, which is crucial for student motivation (Deci and Ryan, 2000). Brewer and Klein (2006) came to a similar conclusion in their investigation of the influence of types of interdependence (roles, rewards, roles plus rewards, no structure) on student interaction. The groups with no structured interdependence had significantly more cognitive interactions involving content discussion than the other groups, indicating that structuring interdependence is not always necessary with university students. We suggest that collaborative learning with university students should be designed using challenging and relevant tasks that build shared ownership with students.

\section{ACKNOWLEDGMENTS}

Drs. Kristin Denzer, Mario Stassen, and Fons Cremers are gratefully acknowledged for encouraging their students to participate in the interviews.

\section{REFERENCES}

Aggarwal P, O'Brien C (2008). Social loafing on group projects: structural antecedents and effect on student satisfaction. J Market Educ 30, 255264.

Barnes J, Conrad K, Demont-Heinrich C, Graziano M, Kowalski D, Neufeld J, Zamora J, Palmquist M (2012). Generalizability and transferability. WritingaCSU, Colorado State University http://writing.colostate.edu/ guides/guide.cfm?guideid=65 (accessed 14 November 2015).

Barron B (2000). Achieving coordination in collaborative problem-solving groups. J Learn Sci 9, 403-436.

Barron B (2003). When smart groups fail. J Learn Sci 12, 307-359.

Berliner DC (2002). Educational research: the hardest science of all. Educ Res 31, 18-20.

Bivins TH (2006). Responsibility and accountability. In: Ethics in Public Relations: Responsible Advocacy, ed. K Fitzpatrick and C Bronstein, Thousand Oaks, CA: Sage, 19-38.

Braun V, Clarke V (2006). Using thematic analysis in psychology. Qual Res Psychol 3, 77-101.

Brewer S, Klein JD (2006). Type of positive interdependence and affiliation motive in an asynchronous collaborative learning environment. Educ Technol Res Dev 54, 331-354.

Burla L, Knierim B, Barth KL, Duetz M, Abel T (2008). From text to codings: intercoder reliability assessment in qualitative content analysis. Nurs Res 57, 111-117.

Chinn CA, O'Donnell AM, Jinks TS (2000). The structure of discourse in collaborative learning. J Exp Educ 69, 77-97.

Cohen EG (1994). Restructuring the classroom: conditions for productive small groups. Rev Educ Res 64, 1-35.

Deci EL, Ryan RM (2000). The "what" and "why" of goal pursuits: human needs and the self-determination of behavior. Psychol Inq 11, 227-268.

Dewey J (1929). The Sources of a Science of Education, New York: Liveright.

Dillenbourg P (2002). Over-scripting CSCL: the risks of blending collaborative learning with instructional design. In: Three Worlds of CSCL. Can We Support CSCL?, ed. PA Kirschner, Heerlen: Open University Nederland, 61-91.

Everitt B (1996). Making Sense of Statistics in Psychology: A Second-Level Course, Oxford, UK: Oxford University Press.

Fink DL (2004). Beyond small groups: harnessing the extraordinary power of learning teams. In: Team-Based Learning: A Transformative Use of Small Groups in Teaching, ed. LK Michaelsen, A Bauman Knight, and LD Fink, Sterling, VA: Stylus, 3-26.

Gillies R (2014). Cooperative learning: developments in research. Int J Educ Psychol 3, 125-140

Gillies RM (2004). The effects of cooperative learning on junior high school students during small group learning. Learn Instr 14, 197-213.

Gully S, Incalcaterra K, Joshi A, Beaubien J (2002). A meta-analysis of team-efficacy, potency, and performance: interdependence and level of analysis as moderators of observed relationships. J Appl Psychol 87, 819-832.

Hall D, Buzwell S (2012). The problem of free-riding in group projects: looking beyond social loafing as reason for non-contribution. Active Learn High Educ 14, 37-49.

Hänze M, Berger R (2007). Cooperative learning, motivational effects, and student characteristics: an experimental study comparing cooperative learning and direct instruction in 12th grade physics classes. Learn Instr 17, $29-41$

Hertz-Lazarowitz R (1989). Cooperation and helping in the classroom: a contextual approach. Int J Res Educ 13, 113-119.

Johnson DW, Johnson RT (1999). Making cooperative learning work. Theory Pract 38, 67-73. 
Johnson DW, Johnson RT (2009). An educational psychology success story: social interdependence theory and cooperative learning. Educ Res 38, 365-379.

Johnson DW, Johnson RT, Smith K (2007). The state of cooperative learning in postsecondary and professional settings. Educ Psychol Rev 19, 15-29.

Kagan S (1994). Cooperative Learning, 2nd ed., San Clemente, CA: Kagan.

Khosa DK, Volet SE (2013). Promoting effective collaborative case-based learning at university: a metacognitive intervention. Stud High Educ 38, 870-889.

Kidd PS, Parshall MB (2000). Getting the focus and the group: enhancing analytical rigor in focus group research. Qual Health Res 10, 293-308.

King A (2002). Structuring peer interaction to promote high-level cognitive processing. Theory Pract 41, 33-39.

Kirschner PA (2001). Using integrated electronic environments for collaborative teaching/learning. Res Dialogue Learn Instruction 2, 1-9.

Kozhevnikov M, Evans C, Kosslyn SM (2014). Cognitive style as environmentally sensitive individual differences in cognition: a modern synthesis and applications in education, business and management. Psychol Sci 15, 3-33.

Langfred CW (2000). The paradox of self-management: individual and group autonomy in work groups. J Organ Behav 21, 563-585.

Lincoln YS, Guba EG (1985). Naturalistic Inquiry, London: Sage.

Linton DL, Farmer JK, Peterson E (2014). Is peer interaction necessary for optimal active learning? CBE Life Sci Educ 13, 243-252.

Livingstone D, Lynch K (2000). Group project work and student-centred active learning: two different experiences. Stud High Educ 25, 325-345.

Lou Y, Abrami P, d'Apollonia S (2001). Small group and individual learning with technology: a meta-analysis. Rev Educ Res 71, 449-521.

Metcalfe M (2005). Generalisation: learning across epistemologies. Forum: Qualitative Social Research 6(1), www.qualitative-research.net/fqs-texte/ 1-05/05-1-17-e.htm (accessed 5 January 2016).

Morgan DL, Spanish MT (1985). Social interaction and the cognitive organisation of health-relevant behavior. Sociol Health Illness 7, 401-422.

Nokes-Malach TJ, Richey JE (2015). When is it better to learn together? Insights from research on collaborative learning. Educ Psychol Rev 27 , 645-656.

Onwegbuezie AJ, Collins KMT, Jiao QG (2009). Performance of cooperative learning groups in a postgraduate education methodology course. Active Learn High Educ 10, 265-277.

Palincsar AS, Herrenkohl LR (2002). Promoting thinking through peer learning. Theory Pract 41, 26-32.

Parkinson TJ, St. George AM (2003). Are the concepts of andragogy and pedagogy relevant to veterinary undergraduate teaching? J Vet Med Educ 30, 247-253.

Pauli R, Mohiyeddini C, Bray D, Michie F, Street B (2008). Individual differences in negative group work experiences in collaborative student learning. Educ Psychol 28, 47-58.

Raidal SL, Volet SE (2009). Preclinical students' predispositions towards social forms of instruction and self-directed learning: a challenge for the development of autonomous and collaborative learners. High Educ 57, 577-596.

Salomon G, Globerson T (1989). When teams do not function the way they ought to. Int J Educ Res 13, 89-99.

Scager K, Akkerman SF, Pilot A, Wubbels T (2014). Challenging high ability students. Stud High Educ 9, 659-680.

Sears DA, Pai H-H (2012). Effects of cooperative versus individual study on learning and motivation after reward-removal. J Exp Educ 80, 246-262.

Serrano JM, Pons RM (2007). Cooperative learning: we can also do it without task structure. Intercultural Educ 18, 215-230.
Shimazou J, Aldrich H (2010). Group work can be gratifying: understanding and overcoming resistance to cooperative learning. Coll Teach 58, 52-57.

Shuell TJ (1996). Teaching and learning in a classroom context. In: Handbook of Educational Psychology, ed. DC Berliner and RC Calfee, New York: MacMillan, 726-763.

Sim C, Wright J (2000). Research in Health Care: Concepts and Methods, Cheltenham, UK: Nelson Thomes.

Slavin RE (1990). Cooperative learning. Rev Educ Res 50, 315-342.

Slavin RE (1991). Group rewards make groupwork work. Educ Leadership 48(5), 89-91.

Slavin RE (1995). Cooperative Learning: Theory, Research, and Practice Boston: Allyn Bacon.

Teasley SD (1995). The role of talk in children's peer collaboration. Dev Psychol 31, 207-220.

Torn A, McNichol E (1998). A qualitative study utilizing a focus group to explore the role and concept of the nurse practitioner. J Adv Nurs 27 1202-1211.

Tsay M, Brady M (2010). A case study of cooperative learning and communication pedagogy: does working in teams make a difference? J Scholarsh Teach Learn 10(2), 78-89.

Van Boxtel C (2000). Collaborative concept learning: collaborative learning tasks, student interaction and the learning of physics concepts. PhD Thesis, Utrecht, Netherlands: Utrecht University.

Van Boxtel C, Van Der Linden J, Kanselaar G (2000). Collaborative learning tasks and the elaboration of conceptual knowledge. Learn Instr 10, 311330 .

Veenman S, Denessen E, Van den Akker A, Van der Rijt J (2005). Effects of a cooperative learning program on the elaborations of students during help seeking and help giving. Am Educ Res J 42, 114-151.

Visschers-Pleijers AJSF, Dolmans DHJM, De Leng BA, Wolfhagen IHAP, Van Der Vleuten CPM (2006). Analysis of verbal interactions in tutorial groups: a process study. Med Educ 40, 129-137.

Volet SE, Summers M, Thurman J (2009). High-level co-regulation in collaborative learning: how does it emerge and how is it sustained? Learn Instr $19,128-143$

Webb NM (2009). The teacher's role in promoting collaborative dialogue in the classroom. Br J Educ Psychol 79, 1-28.

Webb NM, Nemer KM, Zuniga S (2002). Short circuits or superconductors? Effects of group composition on high-achieving students' science assessment performance. Am Educ Res J 39, 943-989.

Webb NM, Palinscar AS (1996). Group processes in the classroom. In: Handbook of Educational Psychology, ed. D Berliner and R Calfee, New York: Macmillan, 841-873.

Wiegant F, Boonstra J, Peeters A, Scager K (2012). Team-based learning in honors science education: the benefit of complex writing assignments. J National Collegiate Honors Council 13, 219-227.

Wiegant F, Scager K, Boonstra J (2011). An undergraduate course to bridge the gap between textbooks and scientific research. CBE Life Sci Educ 10, 83-94.

Wiegant FAC, Scager K, Peeters AJM, Boonstra J (2014). The challenge of writing a PhD proposal in honors (undergraduate) education: a group project as significant learning experience. In: Pursuit of Excellence in a Networked Society: Theoretical and Practical Approaches Coming from the Conference Excellence in Higher Education and Beyond, ed. MVC Wolfensberger, L Drayer, and JJM Volker, Munster, Germany: Waxmann, 77-84.

Wittrock MC (1990). Generative processes of comprehension. Educ Psychol $24,345-376$

Woolley AW, Aggarwal I, Malone TW (2015). Collective intelligence and group performance. Curr Dir Psychol Sci 24, 420-424. 